\title{
A Comparative Study of Fungal and Some Aflatoxin Contents of Freshly Fried and Stored Sallah Meat from Danbatta Local Government Area of Kano State, Nigeria
}

\author{
Fatima S. Abdullahi1 ${ }^{*}$, Amin 0. Igwegbe ${ }^{2 *}$, Bello A. Bello ${ }^{3}$, Mamudu H. Badau2, \\ Sani Abashe ${ }^{3}$, Imaan U. Igwegbe ${ }^{4}$, Zainab Ali ${ }^{5}$ \\ ${ }^{1}$ Department of Food Science and Technology, Federal University Dutsin-ma, Dutsin-ma, Nigeria \\ ${ }^{2}$ Department of Food Science and Technology, University of Maiduguri, Maiduguri, Nigeria \\ ${ }^{3}$ Department of Biochemistry, Federal University Dutse, Dutse, Nigeria \\ ${ }^{4}$ Department of Medical Microbiology, University of Maiduguri Teaching Hospital (UMTH), Miaduguri, Nigeria \\ ${ }^{5}$ Department of Animal of Science, University of Maiduguri, Maiduguri, Nigeria \\ Email: ^amanjide1964@yahoo.com, ^fatysule.fs@gmail.com
}

How to cite this paper: Abdullahi, F.S., Igwegbe, A.O., Bello, B.A., Badau, M.H., Abashe, S., Igwegbe, I.U. and Ali, Z. (2020) A Comparative Study of Fungal and Some Aflatoxin Contents of Freshly Fried and Stored Sallah Meat from Danbatta Local Government Area of Kano State, Nigeria. Open Journal of Medical Microbiology, 10, 71-88.

https://doi.org/10.4236/ojmm.2020.102007

Received: May 11, 2020

Accepted: June 19, 2020

Published: June 22, 2020

Copyright $\odot 2020$ by author(s) and Scientific Research Publishing Inc. This work is licensed under the Creative Commons Attribution International License (CC BY 4.0).

http://creativecommons.org/licenses/by/4.0/

\section{c) (i) Open Access}

\begin{abstract}
A comparative study of Fungi (yeast and moulds) and their toxic metabolites was carried out on offal and muscles of freshly fried and stored Sallah meats from rams, bulls, goats and camels slaughtered for sacrifice in Danbatta Local Government Area, Kano State, Nigeria. The objective was to determine the effects of frying and four weeks storage at ambient temperatures on the mycological loads of the fried and stored meats. A total of seventy two (72) samples of muscles and offal were collected from six different and randomly selected households that slaughtered and fried any of the four animals during that period. The samples were analyzed immediately as freshly fried, and then stored for a period of four weeks during which analyses were conducted at the second and fourth weeks. An analysis of variance (ANOVA) was used to compare between the fungal loads and the toxin contents in the stored meat. Results revealed the presence of Mucor, Rhizopus stolonifer, Aspergillus niger, Saccharomycetes, Penicilium spp and Aspergillus flavus, and that, Aspergillus flavus and Mucor were the highest in the frequency of occurrence among the meat samples. The fungal counts expressed as colony forming units (cfu) per gram of meat, ranged from lowest of $0.43 \times 10^{3}$ and the highest of $5.40 \times 10^{3} \mathrm{cfu} / \mathrm{g}$ in offal of camels and goats, respectively. The results of analyses for aflatoxins revealed the presence of the four types of aflatoxins namely: $B_{1}, B_{2}, G_{1}$ and $G_{2}$, in very few of the samples analyzed. The concentrations, expressed in ppb, were in the order of $B_{1}>B_{2}>G_{2}>G_{1}$ in the
\end{abstract}


muscles and offal of the slaughtered animals; and the toxins were far below the lethal doses recorded in literature. It was concluded that, the fungal organisms were detected in the fried Sallah meats, but not in significant numbers as to cause health risks to the consumers within the short storage time.

\section{Keywords}

Danbatta, Sallah Meat, Aflatoxin, Metabolites, Fried Meat

\section{Introduction}

The term Sallah meat is popularly known as Naman Sallah among the people of Northern parts of Nigeria. It is meat obtained from the scarified slaughter animals during one of the highly celebrated Islamic Festivals (Eidul Kabir); which is a period in Islam that falls in Islamic month of Zul-hijjah (the twelfth month in Islamic Calendar). The animals recommended for the sacrifice must be at least one year old and of different Halal (i.e., not prohibited for consumption) species including cows, bulls, rams, goats sheep, and camels; and must be free from the 4Ds (diseased, downed, disabled, or dead). The sacrifice must be performed depending, on an individual's option that best suits him or her, between the stipulated dates, that is, on the $10^{\text {th }}, 11^{\text {th }}$ and $12^{\text {th }}$ days of the month of Zul-hijjah.

Meat is defined as the edible part of the skeletal muscle of an animal that is healthy at the time of slaughter. It is composed chemically of four major components including water, protein, lipid, carbohydrate and many other minor components such as vitamins, enzymes, pigments and flavour compounds [1]-[9]. The relative proportions of all these constituents give meat its particular structure, texture, flavour, colour and nutritive value. However, because of its unique biological and chemical nature, meat undergoes progressive deterioration from the time of slaughter until consumption [10] [11] [12] [13] [14].

In many developing countries, including Nigeria, meat is widely consumed as a source of protein; it is either eaten cooked or processed into other forms to avoid any form of spoilage [15] [16] [17] [18] [19]. The rapid expansion in meat processing plants in different parts of the world is due to continuous increase in demand for meat products that are highly nutritive, safe and most importantly, affordable [20] [21] [22]. Meat processing, also known as further processing of meat, is the manufacture of meat products from muscle meat, animal fat and certain non-meat additives. Additives are sometimes used to enhance product flavour and appearance [23]. They can also be used to increase product volume. For specific meat preparations, animal by-products such as internal organs, skin or blood, are also well suited for meat processing. Meat processing can create different types of product composition that maximizes the use of edible livestock parts and is tasty, attractive and nourishing [3] [11].

Many foodborne diseases have been associated with consumption of meat and 
its products. Some of the meat carcasses on sale might be contaminated with one pathogen or another and this has been reported to be very common in developing countries [8] [24] [25]. The pathogens of concern in fresh and frozen meat and meat products include, in addition to bacteria, the genera from yeast and moulds that produce myco-toxins in the ready-to-eat products [26] [27].

Myco-toxins are low molecular weight metabolites which cause the harm known as mycotoxicosis, in livestock, domestic animals and humans and therefore are of public health significance [28] [29]. The production of myco-toxins is stimulated by certain environmental factors. Therefore the extent of contamination will differ with geographic location, agricultural methods and the susceptibility of commodities to the penetration of fungi particularly during storage periods [30]. Fungi that produce toxins in food are classified into field and storage fungi based on their ecological requirements for growth [31] [32]. The toxins, which may be secondary metabolites, are produced by filamentous fungi which may contaminate foods at any stage during production and storage [29] [32] [33] [34] [35]. The common genera of mycotoxigenic fungi that have been associated with food items are: Aspergillus, Penicillium, Fusarium, Trichoderma, Trichothecium and Alternaria [27] [28] [35]. Mycotoxins, particularly aflatoxins (AFTs) and ochratoxin A (OTA) pose a significant threat to human health. Aflatoxins are potential carcinogens and, are usually associated with hepatitis $B$ virus. They have been implicated in many thousands of human deaths per annum, mostly in non-industrialized tropical countries [35] [36] [37]. AFTs are the secondary metabolites such as $\mathrm{B}_{\mathrm{I}}, \mathrm{B}_{2}, \mathrm{G}_{1}, \mathrm{G}_{2}$ and difuranocoumarins that are produced by $A$. flavus and $A$. parasiticus that are commonly found in foods and feeds and have been associated with various diseases such as aflatoxicosis in livestock, domestic animals and humans throughout the world [28].

The practice of storing the Sallah meat for an extended period is very common among the inhabitants of Danbatta Local Government Area (LGA) in Kano State, Nigeria. There is limited information on the possible effects of this storage at normal ambient temperatures on the mycological contents of the stored meat at the time of consumption. This study is therefore designed to investigate the possible presence of fungi and their toxins in the meat products during the extend period of the storage at ambient temperatures.

\section{Materials and Methods}

\subsection{Sample Collection}

Danbatta LGA in Kano State was chosen for this study, because of the habits of the inhabitants of storing the fried Sallah meat for a long period after the Sallah celebrations. Samples (200 g each) of freshly fried Sallah meats were collected directly from randomly selected households in the area at the evening hours (4 $7 \mathrm{pm}$ ) of the $10^{\text {th }}$ to $12^{\text {th }}$ of the Holy Month of Zul-Hijjah, in previously sterilized containers, and then transported to the laboratories for the mycological assessments. The samples used in the assessments were the edible parts consisting of 
the muscles and offal from the slaughtered (scarified) rams, bulls, goats and camels. A total of 72 samples were collected from six different households for each type of the four sacrificial animals and the analyses were conducted in triplicates. The analyses were carried out at two weeks interval, starting from zero to the fourth week which is the maximum period the Sallah meat is usually stored by the inhabitants at ambient temperatures.

\subsection{Sample Preparation}

The meat samples were thoroughly grind using previously sterilized pestles and mortars and $11 \mathrm{~g}$ were transferred into $99 \mathrm{~mL}$ of sterile peptone water, and then shaken thoroughly to make a homogenous mixture (these served as stock solutions for each sample). Serial dilutions were made using $1 \mathrm{ml}$ from the stock homogenate and $9 \mathrm{ml}$ of sterile distilled water. Several dilutions were made, up to 5 folds $\left(\right.$ i.e., $10^{5}$ ) for each sample, in order to obtain discrete colonies as described in [38] [39].

\subsection{Preparation of Media}

The following media were used in the mycological assessment: potato dextrose agar (PDA) and eosine methylene blue agar (EMBA) for mold and yeast counts, respectively. These media were used for the enumeration of the fungi as well as in the pure culture selection of the organisms; each medium was prepared as instructed by their manufacturers. All glassware, including Petri-dish, test tubes, pipettes, flasks and bottles used in the analysis were sterilized in a hot oven at $170^{\circ} \mathrm{C} \pm 5^{\circ} \mathrm{C}$ for at least two hours, while the media and distilled water were sterilized by autoclaving at $121^{\circ} \mathrm{C}$ for $15 \mathrm{~min}$, at $15 \mathrm{psi}$ [9] [39]. Plating was carried out in triplicate and pour plate method was used to make the viable counts [40] [41] [42]. In this method, one (1) $\mathrm{ml}$ of the inoculums was mixed thoroughly in molten plate count agar held in a hot water bath at $47^{\circ} \mathrm{C} \pm 2^{\circ} \mathrm{C}$. The agar was allowed to set; the plates were inverted and then incubated at $25^{\circ} \mathrm{C}$ for $5-7$ days for yeast and mold counts [43]. For each dilution, the viable colonies, which appeared colorless, in the three plates were counted and the means were calculated.

\section{Characterization of the Fungal Isolates}

The fungi were identified using lactophenol cotton blue technique. In this process, a drop of lactophenol cotton blue was placed on the grease free slide. A straight wire loop was used to pick the organism from the colony and placed on the drop. A cover slip was placed on the lactophenol cotton blue and examined under a microscope (X4 objective lens) to check for the morphological characteristic of the organisms [43].

\section{Mycological Analysis Using a High Performance Liquid Chromatography (HPLC)}

In preparation for an HPLC analysis, $40 \mathrm{~mL}$ of $84 \%$ (v/v) acetonitrile/methanol 
was added to $10 \mathrm{~g}$ of the sample and then homogenized for 3 min with a homogenizer, poured into a $100 \mathrm{~mL}$ centrifuge tube, the homogenate was centrifuged at $10,000 \mathrm{rpm}$ for $10 \mathrm{~min}$ at $4^{\circ} \mathrm{C} ; 16 \mathrm{~mL}$ of the supernatant was evaporated to dryness under a stream of Nitrogen at $50^{\circ} \mathrm{C}$. The residue was re-dissolved using $8 \mathrm{~mL}$ of a mixture of ethylacetate/cyclohaxane $(50: 50 \mathrm{v} / \mathrm{v})$, filtered with $0.45 \mu \mathrm{m}$ nylon filter paper, the filtrate was again dried using a rotary evaporator and the residue was then re-dissolved in $1 \mathrm{~mL}$ of methanol/10 $\mathrm{mMol} / \mathrm{L}$ ammonium acetate $(1: 1 \mathrm{v} / \mathrm{v})$. Finally, the solution was passed through $0.22 \mu \mathrm{m}$ nylon filter paper prior to injection into the HPLC [44]. The excitation and emission wavelengths for the aflatoxin detection were set at $360 \mathrm{~nm}$ and 450 $\mathrm{nm}$, respectively.

\section{Conditioning of the HPLC for Analysis}

The analyte was separated by a HPLC system (consisting of vacuum degasser, auto-sampler and a binary pump (Agilent Series 1200, Agilent Technologies, Santa Clara, CA, USA) equipped with a ZORBAX Eclipse Plus C18 column (1.8 $\mu \mathrm{m}, 2.1 \times 100 \mathrm{~mm}$ ). The column temperature was maintained at $35^{\circ} \mathrm{C}$. The injection volume was $20 \mu \mathrm{l}$, and the gradient elution was used in Liquid Chromatographic step with a mobile phase consisting of solvent A $(10 \mathrm{mmol} / \mathrm{L} \mathrm{ammo-}$ nium acetate was used for the ESI+ mode and $0.1 \%(\mathrm{v} / \mathrm{v})$ aqueous ammonia was used for the ESI-mode) and solvent $B$ (methanol) at follow rates: 0 - 2.0 min, $40 \%$ B - 60\% B; 2.0 - $7.0 \min 60 \%$ B - 95\% B; 7.0 - $9.0 \mathrm{~min}, 95 \%$ B; 9.0 - $9.5 \mathrm{~min}$, $95 \%$ B - 40\% B. A subsequent re-equilibration time ( $2 \mathrm{~min}$ ) was performed before the next injection [44].

\section{Statistical Analysis}

This study was designed as a complete randomized design (CRD) and the results obtained were subjected to a one way analysis of variance (ANOVA). The test for significance among means was carried out using the Tukey's Honest Significant Difference (HSD) Test at 5\% level of significance [45].

\section{Results and Discussions}

The muscles of healthy animals are usually regarded as sterile, but the slaughtering and butchering processes can provide microorganisms with an opportunity to colonize the meat surfaces. Contamination of meat is a continuing possibility from the moment of exsanguinations of the meat animals until consumption. In the abattoir itself there are many potential sources of contamination of meat by microorganisms. These include the animal hide and hair, soil adhering thereto, the contents of the gastrointestinal tract (especially if inadvertently released during dressing operations), airborne contamination, aqueous sources (the water used for washing the carcass, or for cleaning the floors and equipment), the instruments used in dressing (knives, saws, cleavers and hooks), various vessels and receptacles, and the personnel [9] [39] [42] [46]. The aerosols 
produced during de-hiding, evisceration, and carcass splitting are also important sources of contamination [20]. Air circulated from heavily contaminated refrigeration coils in meat and poultry processing plants can also serve as potential sources of contamination. The initial microbial load of a carcass surface is determined by the hygiene observed during the slaughtering operations as well as handling practices [47]. The observations recorded in the present study are presented in Tables 1-10 with some of their statistical interpretations. To start with, the total fungal counts, expressed in colony-forming unit $\left(\mathrm{cfu} \times 10^{3}\right)$ per gram of different parts of the fried Sallah meat, recorded in this study are presented in Table 1, with their standard deviations. Statistically, significant differences $(\mathrm{P} \leq$ 0.05 ) were observed between the fungal contents of the freshly fried meat parts (muscles and offal) in the zero weeks and that of the second and fourth weeks of the storage periods. The initial fungal loads were generally found to be less in the freshly fried meats when compared with the stored ones, though in most cases, no significant differences $(P \geq 0.05)$ were observed between the fungal loads of the meat parts during the second and fourth weeks of the storage (Table 1). In overall, the lowest fungal counts, $0.27 \pm 0.06$, was recorded from the muscles of camels at zero week, whereas the highest, $6.37 \pm 2.11$, was from the goats' offal during the fourth week of the storage period. The gradual increase in fungal counts as the storage period progressed may be as result of surface contaminants or due to the gradual lost in water activity $\left(\mathrm{a}_{\mathrm{w}}\right)$ which makes the fried meat environment more conducive for the growth of yeast and moulds. Foods are described

Table 1. Mean fungal counts $\left(\mathrm{cfu} / \mathrm{g} \times 10^{3}\right)$ recorded in muscles and offal of ram, bull, goat and camel during the four weeks of storage of the Sallah meats at ambient temperatures ${ }^{1}$.

\begin{tabular}{cccc}
\hline & \multicolumn{3}{c}{ Storage Period (Weeks) $^{2}$} \\
Species/Part & 0 & 2 & 4 \\
\cline { 2 - 4 } Ram & & $3.30 \pm 2.43^{\mathrm{b}}$ & $4.53 \pm 3.35^{\mathrm{b}}$ \\
Muscle & $0.60 \pm 0.17^{\mathrm{a}}$ & $5.93 \pm 4.29^{\mathrm{b}}$ \\
Offal & $0.30 \pm 0.17^{\mathrm{a}}$ & $6.03 \pm 1.85^{\mathrm{b}}$ & \\
Bull & & & $3.07 \pm 2.97^{\mathrm{b}}$ \\
Muscle & $0.50 \pm 0.20^{\mathrm{a}}$ & $2.87 \pm 0.49^{\mathrm{b}}$ & $2.00 \pm 1.65^{\mathrm{b}}$ \\
Offal & $0.57 \pm 0.15^{\mathrm{a}}$ & $2.43 \pm 1.02^{\mathrm{b}}$ & \\
Goat & & & $2.97 \pm 2.72^{\mathrm{b}}$ \\
Muscle & $0.60 \pm 0.20^{\mathrm{a}}$ & $1.83 \pm 1.10^{\mathrm{b}}$ & $6.37 \pm 2.11^{\mathrm{c}}$ \\
Offal & $0.50 \pm 0.26^{\mathrm{a}}$ & $2.97 \pm 2.04^{\mathrm{b}}$ & \\
Camel & & & $3.43 \pm 4.04^{\mathrm{c}}$ \\
Muscle & $0.27 \pm 0.06^{\mathrm{a}}$ & $5.40 \pm 3.27^{\mathrm{b}}$ & $4.67 \pm 3.27^{\mathrm{c}}$ \\
Offal & $0.40 \pm 0.35^{\mathrm{a}}$ & $2.57 \pm 1.33^{\mathrm{b}}$ &
\end{tabular}

${ }^{1}$ Values are means of triplicate determinations \pm Standard Deviations; ${ }^{2}$ In any raw, means bearing similar superscripts are not significantly different $(\mathrm{P} \geq 0.05)$. 
as dry or low-moisture foods if they have very low water content. These are most often solid food systems such as the fried Sallah meat investigated in this study. This observation is also in line with those made by [13] [48] [49] [50]. This result has, however, confirmed the presence of fungal organisms in the fried Sallah meats, though not in significant numbers as to cause health risks to the consumers within the short storage time.

Results of Isolation and Identification of the Fungal Contents of the Sallah Meat.

The control of water activity in foods is an important tool for extending shelf life of food products. It is responsible for the quality of foods affected by microbiological, chemical, and physical changes. It has been proven that physical properties, quantity, and quality of water within the food have a strong impact on food effectiveness, quality attributes, shelf life, textural properties, and processing [13] [50]. Food preservation processes have a common goal of extending the shelf life of foods to allow for storage and convenient distribution. The activity of microorganisms is the first and most dangerous limitation of shelf life. Water is essential for microorganisms that may cause food spoilage if they are present in a food that offers them favorable conditions for growth. Hence, many food preservation techniques were developed to reduce the availability or activity of water in order to eliminate the dangers of microbial spoilage. Mycotoxins, on the other hand, are the toxic products of certain microscopic fungi which, in some circumstances, develop on or in foodstuffs of plant or animal origin. They are ubiquitous in nature and could become potential contaminants at all levels of the food chain. Hundreds of mycotoxins have been identified and are produced by some 200 varieties of fungi [26] [35] [37] [51]. The lists of fungi isolated and identified in this study are presented in Tables 2-5, together with their morphological and microscopic descriptions; and they include: Mucor, Rhizopus stolonifer, Aspergillus niger, Saccharomycetes, Penicilium spp and Aspergillus flavus. The Tables are quite self explanatory.

Similarly, the frequency of occurrence of each fungus in the fried Sallah meat samples, expressed in percentage, is presented in Tables 6-9, for the four weeks period of storage. If there is fungal growth, mycotoxins may be produced. The existence of fungi in a food product, however, does not necessarily signify the presence of mycotoxins. Furthermore, the absence of fungal growth on a food commodity does not indicate that it is free from mycotoxins because toxins can exist after the fungi have disappeared. Moreover, in the present study, the most frequently recorded fungi, especially during the fourth week of the storage period, were Mucor and $R$. stolonifer. The highest frequency of occurrence of the two fungi, $53.48 \%$ and $46.39 \%$, respectively, were recorded in the offal of the camels and rams (Table 6 and Table 9), whereas the highest frequency of the fungi recorded in the muscles were $40.84 \%$ and $51.88 \%$ for goats and bulls, respectively (Table 7 and Table 8); and Saccharomycete was the least in the frequency of occurrence among all the fungi isolated, especially from the second to 
Table 2. Morphological and microscopic characterization of fungal isolates in muscles and offal of fried and stored Sallah meat of rams.

\begin{tabular}{|c|c|c|c|}
\hline $\begin{array}{l}\text { Type of } \\
\text { Meat }\end{array}$ & Morphological Description of Colonies & Microscopic Appearance & $\begin{array}{l}\text { Suspected } \\
\text { Organism }\end{array}$ \\
\hline \multirow[t]{5}{*}{ Muscles } & White cottony at first then grey as it grow older & $\begin{array}{l}\text { Sporangiophores arise singly from mycelium at any point. All } \\
\text { branches terminate in sporangia }\end{array}$ & Mucor \\
\hline & $\begin{array}{l}\text { Black dusty and spongy throughout the storage } \\
\text { time }\end{array}$ & $\begin{array}{l}\text { Sporangiophores arises from long arching stolons opposite } \\
\text { rhizoids }\end{array}$ & Rhizopus stolonifer \\
\hline & Dark-brown to black pigmentation & $\begin{array}{l}\text { Numerous mycelia conidiophores are black, spherical to oval, } \\
\text { produced in long chain }\end{array}$ & Aspergillus niger \\
\hline & Colony appeared to be circular, white and creamy & Single cells, oval in shape with some cells showing budding & Saccharomycetes \\
\hline & Pinkish surface with white underneath & $\begin{array}{l}\text { Conidiophores bear branched sterigmata, each with chain of } \\
\text { conidiophores }\end{array}$ & Peniciliumspp \\
\hline \multirow[t]{5}{*}{ Offal } & Darkish-brown to black pigmentation & $\begin{array}{l}\text { Numerous mycelia conidiophores are black, spherical to oval, } \\
\text { produced in long chain }\end{array}$ & Aspergillus niger \\
\hline & $\begin{array}{l}\text { Yellowish green surface with reddish brown } \\
\text { underneath }\end{array}$ & $\begin{array}{l}\text { The apex of the conidiophores is swollen into a vesicle from } \\
\text { which arises bottle shaped cells, sterigmata which bear chains of } \\
\text { secondary sterigma }\end{array}$ & Aspergillus flavus \\
\hline & White cottony at first then grey as it grow older & $\begin{array}{l}\text { Sporangiophores arise singly from mycelium at any point. All } \\
\text { branches terminate in sporangia }\end{array}$ & Mucor \\
\hline & $\begin{array}{l}\text { Black dusty and spongy throughout the storage } \\
\text { time }\end{array}$ & $\begin{array}{l}\text { Sporangiophores arises from long arching stolons opposite } \\
\text { rhizoids }\end{array}$ & Rhizopus stolonifer \\
\hline & Pinkish surface with white underneath & $\begin{array}{l}\text { Conidiophores bear branched sterigmata, each with chain of } \\
\text { conidiophores }\end{array}$ & Penicilium spp \\
\hline
\end{tabular}

Table 3. Morphological and microscopic characterization of fungal isolates in muscles and offal of fried and stored Sallah meat of bulls.

\begin{tabular}{llll}
\hline $\begin{array}{l}\text { Type of } \\
\text { Meat }\end{array}$ & Morphological Description of Colonies & Microscopic Appearance & $\begin{array}{l}\text { Suspected } \\
\text { Organism }\end{array}$ \\
\hline Muscles Pink surface with white colour underneath & $\begin{array}{l}\text { Conidiophores bear branched sterigmata, each with chain of } \\
\text { conidiophores }\end{array}$ & Penicilium spp \\
$\begin{array}{l}\text { Yellow green surface with reddish brown } \\
\text { underneath }\end{array}$ & $\begin{array}{l}\text { The apex of the conidiophores is swollen into a vesicle from } \\
\text { which arises bottle shaped cells, sterigmata which bear chains of } \\
\text { secondary sterigma }\end{array}$ & Aspergillus flavus \\
$\begin{array}{l}\text { Colony appeared to be round, white and } \\
\text { creamy }\end{array}$ & $\begin{array}{l}\text { Single cells oval in shape with some cells showing budding } \\
\text { Black dusty and spongy throughout the } \\
\text { storage time }\end{array}$ & $\begin{array}{l}\text { Sporangiophores arise from long arching stolons opposite } \\
\text { rhizoids }\end{array}$ & Rhizopus stolonifer \\
$\begin{array}{l}\text { Darkish-brown colour to black pigmentation } \\
\text { Numerous mycelia with black conidiopores spherical to oval, } \\
\text { produced in long chain }\end{array}$ & Aspergillus niger \\
$\begin{array}{l}\text { Whitish cottony at first then grey as it grow } \\
\text { older }\end{array}$ & $\begin{array}{l}\text { Sporangiophores arise singly from mycelium at any point. All } \\
\text { branches terminate in sporangia }\end{array}$ & Mucor
\end{tabular}




\section{Continued}

Offal Colony appeared to be round, white and creamy

Darkish-brown colour to black pigmentation

Black dusty and spongy throughout the storage time

Pink colour surface with white underneath

Yellow green surface with reddish brown underneath

Whitish cottony at first then grey as it grow older
Single cells oval in shape with some cells showing budding

Saccharomycetes

Numerous mycelia conidiophores are black, spherical to oval, produced in long chain

Sporangiophores arise from long arching stolons opposite rhizoids

Conidiophores bear branched sterigmata, each with chain of conidiophores

The apex of the conidiophores is swollen into a vesicle from which arises bottle shaped cells, sterigmata which bear chains of secondary sterigma

Sporangiophores arise singly from mycelium at any point. All Mucor branches terminate in sporangia

Aspergillus niger

Penicilium spp

Aspergillus flavus
Rhizopus stolonifer

Table 4. Morphological and microscopic characterization of fungal isolates in muscles and offal of fried and stored Sallah meat of goats.

\begin{tabular}{|c|c|c|c|}
\hline $\begin{array}{l}\text { Type of } \\
\text { Meat }\end{array}$ & Morphological Description of Colonies & Microscopic Appearance & $\begin{array}{l}\text { Suspected } \\
\text { Organism }\end{array}$ \\
\hline \multirow[t]{6}{*}{ Muscles } & $\begin{array}{l}\text { Whitish cottony at first then grey as it grow } \\
\text { older }\end{array}$ & $\begin{array}{l}\text { Sporangiophores arise singly from mycelium at any point. All } \\
\text { branches terminate in sporangia }\end{array}$ & Mucor \\
\hline & $\begin{array}{l}\text { Dusty, black and spongy throughout the } \\
\text { storage time }\end{array}$ & $\begin{array}{l}\text { Sporangiophores arise from long arching stolons opposite } \\
\text { rhizoids }\end{array}$ & Rhizopus stolonifer \\
\hline & Dark-brown to black pigmentations & $\begin{array}{l}\text { Numerous mycelia conidiophores are black, spherical to oval, } \\
\text { produced in long chain }\end{array}$ & Aspergillus niger \\
\hline & $\begin{array}{l}\text { Colony appeared to be circular, white and } \\
\text { creamy }\end{array}$ & Single cells oval in shape with some cells showing budding & Saccharomycetes \\
\hline & $\begin{array}{l}\text { Pinkish colour surface with white } \\
\text { underneath }\end{array}$ & $\begin{array}{l}\text { Conidiophores bear branched sterigmata, each with chain of } \\
\text { conidiophores }\end{array}$ & Penicilium spp \\
\hline & $\begin{array}{l}\text { Yellow green surface with reddish brown } \\
\text { underneath }\end{array}$ & $\begin{array}{l}\text { The apex of the conidiophores is swollen into a vesicle from } \\
\text { which arises bottle shaped cells, sterigmata which bear chains of } \\
\text { secondary sterigma }\end{array}$ & Aspergillus flavus \\
\hline \multirow[t]{5}{*}{ Offal } & Pink colour surface with white underneath & $\begin{array}{l}\text { Conidiophores bear branched sterigmata, each with chain of } \\
\text { conidiophores }\end{array}$ & Penicilium spp \\
\hline & $\begin{array}{l}\text { Yellowish green surface with reddish brown } \\
\text { underneath }\end{array}$ & $\begin{array}{l}\text { The apex of the conidiophores is swollen into a vesicle from } \\
\text { which arises bottle shaped cells, sterigmata which bear chains of } \\
\text { secondary sterigma }\end{array}$ & Aspergillus flavus \\
\hline & $\begin{array}{l}\text { Colony appeared to be round, white and } \\
\text { creamy }\end{array}$ & Single cells oval in shape with some cells showing budding & Saccharomycetes \\
\hline & $\begin{array}{l}\text { Black, dusty and spongy throughout the } \\
\text { storage time }\end{array}$ & $\begin{array}{l}\text { Sporangiophores arises from long arching stolons opposite } \\
\text { rhizoids }\end{array}$ & Rhizopus stolonifer \\
\hline & Dark-brown to black pigmentation & $\begin{array}{l}\text { Numerous mycelia conidiophores are black, spherical to oval, } \\
\text { produced in long chain }\end{array}$ & Aspergillus niger \\
\hline
\end{tabular}


Table 5. Morphological and microscopic characterization of fungal isolates in muscles and offal of fried and stored Sallah meat of camels.

\begin{tabular}{|c|c|c|c|}
\hline $\begin{array}{l}\text { Type of } \\
\text { Meat }\end{array}$ & Morphological Description of Colonies & Microscopic Appearance & Suspected Organism \\
\hline \multirow[t]{5}{*}{ Muscles } & White cottony at first then grey as it grow older & $\begin{array}{l}\text { Sporangiophores arise singly from mycelium at any point. } \\
\text { All branches terminate in sporangia }\end{array}$ & Mucor \\
\hline & Black dusty and spongy & $\begin{array}{l}\text { Sporangiophores arises from long arching stolons opposite } \\
\text { rhizoids }\end{array}$ & Rhizopus stolonifer \\
\hline & Colony appeared to be circular, white and creamy & Single cells oval in shape with some cells showing budding & Saccharomycetes \\
\hline & Pinkish surface with white underneath & $\begin{array}{l}\text { conidiophores bear branched sterigmata, each with chain of } \\
\text { conidiophores }\end{array}$ & Penicilium spp \\
\hline & $\begin{array}{l}\text { Yellowish green surface with reddish brown } \\
\text { underneath }\end{array}$ & $\begin{array}{l}\text { The apex of the conidiophores is swollen into a vesicle from } \\
\text { which arises bottle shaped cells, sterigmata which bear } \\
\text { chains of secondary sterigma }\end{array}$ & Aspergillus flavus \\
\hline \multirow[t]{6}{*}{ Offal } & White cottony at first then grey as it grow older & $\begin{array}{l}\text { Sporangiophores arise singly from mycelium at any point. } \\
\text { All branches terminate in sporangia }\end{array}$ & Mucor \\
\hline & Black dusty and spongy & $\begin{array}{l}\text { Sporangiophores arises from long arching stolons opposite } \\
\text { rhizoids }\end{array}$ & Rhizopus stolonifer \\
\hline & Dark-brown to black pigmentation & $\begin{array}{l}\text { Numerous mycelia, conidiophores are black, spherical to } \\
\text { oval, produced in long chain }\end{array}$ & Aspergillus niger \\
\hline & Colony appeared to be circular, white and creamy & Single cells oval in shape with some cells showing budding & Saccharomycetes \\
\hline & Pinkish surface with white underneath & $\begin{array}{l}\text { Conidiophores bear branched sterigmata, each with chain of } \\
\text { conidiophores }\end{array}$ & Peniciliumspp \\
\hline & $\begin{array}{l}\text { Yellowish green surface with reddish brown } \\
\text { underneath }\end{array}$ & $\begin{array}{l}\text { The apex of the conidiophores is swollen into a vesicle from } \\
\text { which arises bottle shaped cells, sterigmata which bear } \\
\text { chains of secondary sterigma }\end{array}$ & Aspergillus flavus \\
\hline
\end{tabular}

Table 6. Frequency of occurrence of the six fungal isolates in muscles and offal from rams during the four weeks storage period.

\begin{tabular}{|c|c|c|c|c|}
\hline \multirow{2}{*}{ Type of Meat } & \multirow{2}{*}{ Bacteria } & \multicolumn{3}{|c|}{ Frequency of occurrence (\%)/Week ${ }^{*}$} \\
\hline & & 0 & 2 & 4 \\
\hline \multirow[t]{6}{*}{ Muscles } & Mucor & 33.33 & 43.13 & 48.75 \\
\hline & Aspergillus flavus & 14.67 & 14.38 & 8.91 \\
\hline & Rhizopus stolonifer & 21.33 & 16.88 & 35.93 \\
\hline & Aspergillus niger & 16.00 & 14.38 & 4.74 \\
\hline & Saccharomycete & 2.67 & 1.88 & - \\
\hline & Penicillium spp & 12.00 & 9.38 & 1.67 \\
\hline \multirow[t]{6}{*}{ Offal } & Mucor & 27.45 & 32.68 & 41.37 \\
\hline & Aspergillus flavus & 39.22 & 14.38 & 5.82 \\
\hline & Rhizopus stolonifer & 13.73 & 19.61 & 46.39 \\
\hline & Aspergillus niger & 7.84 & 22.88 & 3.61 \\
\hline & Saccharomycete & 1.96 & - & - \\
\hline & Penicillium spp & 9.80 & 10.46 & 2.81 \\
\hline
\end{tabular}

*Values are means of triplicate determinations. 
Table 7. Frequency of occurrence of the six fungal isolates in muscles and offal from bulls during the four weeks storage period.

\begin{tabular}{clccc}
\hline \multirow{2}{*}{ Type of Meat } & \multicolumn{3}{c}{ Bacteria } & \multicolumn{2}{c}{ Frequency of Occurrence (\%)/Week } \\
\cline { 3 - 5 } Muscles & Mucor & 30.65 & 32.54 & 4 \\
\cline { 2 - 4 } & Aspergillus flavus & 17.74 & 10.06 & 5.29 \\
& Rhizopus stolonifer & 20.97 & 29.59 & 36.69 \\
& Aspergillus niger & 16.13 & 14.20 & 1.88 \\
& Saccharomycete & 3.23 & 3.55 & - \\
& Penicillium spp & 11.29 & 10.06 & 4.26 \\
& Mucor & 31.33 & 33.39 & 42.14 \\
& Aspergillus flavus & 20.48 & 8.19 & 6.02 \\
& Rhizopus stolonifer & 20.48 & 31.58 & 33.20 \\
& Aspergillus niger & 16.87 & 11.70 & 1.55 \\
& Saccharomycete & 1.20 & 4.68 & - \\
& Penicillium spp & 9.64 & 10.53 & 17.09 \\
\hline
\end{tabular}

*Values are means of triplicate determinations.

Table 8. Frequency of occurrence of the six fungal isolates in muscles and offal from goats during the four weeks storage period.

\begin{tabular}{|c|c|c|c|c|}
\hline \multirow{2}{*}{ Type of Meat } & \multirow{2}{*}{ Bacteria } & \multicolumn{3}{|c|}{ Frequency of Occurrence (\%)/Week* } \\
\hline & & 0 & 2 & 4 \\
\hline \multirow[t]{6}{*}{ Muscles } & Mucor & 16.67 & 24.48 & 40.84 \\
\hline & Aspergillus flavus & 12.70 & 11.89 & 5.84 \\
\hline & Rhizopus stolonifer & 48.41 & 19.58 & 40.84 \\
\hline & Aspergillus niger & 12.70 & 23.08 & 4.83 \\
\hline & Saccharomycete & 0.79 & 6.99 & - \\
\hline & Penicillium $s p p$ & 8.73 & 13.99 & 7.65 \\
\hline \multirow[t]{6}{*}{ Offal } & Mucor & 22.95 & 24.71 & 42.36 \\
\hline & Aspergillus flavus & 18.03 & 13.22 & 7.82 \\
\hline & Rhizopus stolonifer & 22.95 & 24.71 & 25.27 \\
\hline & Aspergillus niger & 13.11 & 25.86 & 11.45 \\
\hline & Saccharomycete & 11.48 & 2.87 & - \\
\hline & Penicillium spp & 11.48 & 8.62 & 13.09 \\
\hline
\end{tabular}

*Values are means of triplicate determinations.

the fourth weeks of the storage periods. The variations in frequency of occurrence (\%) observed in this study could be due to differences in meat parts and treatment/processes used by individual households in the preparation and frying of the Sallah meat. This observation is in line with the findings of Igene et al. 
Table 9. Frequency of occurrence of the six fungal isolates in muscles and offal from camels during the four weeks storage period.

\begin{tabular}{|c|c|c|c|c|}
\hline \multirow{2}{*}{ Type of Meat } & \multirow{2}{*}{ Bacteria } & \multicolumn{3}{|c|}{ Frequency of Occurrence (\%)/Week ${ }^{*}$} \\
\hline & & 0 & 2 & 4 \\
\hline \multirow[t]{6}{*}{ Muscles } & Mucor & 25.00 & 30.41 & 36.41 \\
\hline & Aspergillus flavus & 25.00 & 12.41 & 5.27 \\
\hline & Rhizopus stolonifer & 27.27 & 22.30 & 37.23 \\
\hline & Aspergillus niger & 9.09 & 20.27 & 9.39 \\
\hline & Saccharomycete & 4.55 & 0.68 & - \\
\hline & Penicillium spp & 9.09 & 14.19 & 11.70 \\
\hline \multirow[t]{6}{*}{ Offal } & Mucor & 22.67 & 26.29 & 53.48 \\
\hline & Aspergillus flavus & 21.33 & 8.57 & 7.17 \\
\hline & Rhizopus stolonifer & 16.00 & 26.86 & 23.70 \\
\hline & Aspergillus niger & 18.67 & 21.14 & 8.48 \\
\hline & Saccharomycete & 1.33 & 2.86 & - \\
\hline & Penicillium spp & 20.00 & 14.86 & 7.17 \\
\hline
\end{tabular}

*Values are means of triplicate determinations.

[21] which stated that the quality of meat and meat products produced by processors varies from one processor to another due to lack of standard methods of preparation that would ensure consistent product quality.

Results of Quantification of the Mycotoxins Contents of the Sallah Meat with HPLC:

The best approach to eliminating mycotoxins from food is to prevent fungal growth at all levels of production, harvesting, transporting, processing, storage, and marketing. Among all the mycotoxins, aflatoxin is considered to pose the greatest potential hazard to human health. It is produced by A. flavus and A. parasiticus, which are nearly ubiquitous with spores that can widely be disseminated by air currents. Among these two fungi, only A. flavus was identified and isolated in this study and its frequency of occurrence was not significant, especially between the second and fourth weeks of the storage periods. However, the aflatoxin contents of the fried and stored Sallah meats as determined by HPLC and expressed in parts per billion (ppb), are presented in Table 10. The four types of aflatoxins, $B_{1}, B_{2}, G_{1}$ and $G_{2}$, were not detected in the majority of the meat parts analyzed. Moreover, the highest levels recorded were $7.73 \pm 0.72,5.35$ \pm 0.85 and $5.10 \pm 0.72 \mathrm{ppb}$ of $\mathrm{B}_{1}, \mathrm{~B}_{2}$, and $\mathrm{G}_{2}$, respectively, obtained from the muscles of rams, camels and goats (Table 10). These values are still far below the Lethal Dosage $\left(\mathrm{LD}_{50}\right)$ recorded in literatures in most animal experiments, which ranged from 0.5 to $10 \mathrm{mg} / \mathrm{kg}$ (ppm) body weight [27] [30] [31] [32] [36]. The complete absence or low levels of aflatoxins recorded in this study is in correlation with the fact that the majority of fungi isolated from the fried and stored Sallah meats were not of the types known to produce aflatoxins in foods, which 
Table 10. Mean Aflatoxins $\mathrm{B}_{1}, \mathrm{~B}_{2} \mathrm{G}_{1}$ and $\mathrm{G}_{2}$ content (ppb) of freshly fried and stored sallah meats recorded in muscles and offal from the four animal types during the four weeks storage periods*.

\begin{tabular}{|c|c|c|c|c|c|c|c|c|}
\hline \multirow{3}{*}{$\begin{array}{c}\text { Type of } \\
\text { Animal/Storage } \\
\text { Period (Week) }\end{array}$} & \multicolumn{8}{|c|}{ Aflatoxins (ppb)/Type of Meat ${ }^{1}$} \\
\hline & \multicolumn{4}{|c|}{ Muscles $^{2}$} & \multicolumn{4}{|c|}{ Offal $^{2}$} \\
\hline & $\mathrm{B}_{1}$ & $\mathrm{~B}_{2}$ & $\mathrm{G}_{1}$ & $\mathrm{G}_{2}$ & $\mathrm{~B}_{1}$ & $\mathrm{~B}_{2}$ & $\mathrm{G}_{1}$ & $\mathrm{G}_{2}$ \\
\hline \multicolumn{9}{|l|}{ Rams: } \\
\hline 0 & ND & ND & ND & ND & ND & ND & ND & ND \\
\hline 2 & ND & ND & ND & ND & ND & ND & ND & ND \\
\hline 4 & $7.73 \pm 0.72^{\mathrm{a}}$ & $1.14 \pm 0.71^{\mathrm{a}}$ & $2.82 \pm 0.59^{\mathrm{b}}$ & $0.34 \pm 0.06^{\mathrm{a}}$ & ND & ND & ND & ND \\
\hline \multicolumn{9}{|l|}{ Bulls: } \\
\hline 0 & ND & ND & ND & ND & ND & ND & $0.39 \pm 0.09^{\mathrm{a}}$ & ND \\
\hline 2 & ND & $0.44 \pm 0.40^{\mathrm{a}}$ & ND & ND & $0.45 \pm 0.40^{\mathrm{a}}$ & $0.45 \pm 0.40^{\mathrm{a}}$ & $0.52 \pm 0.07^{\mathrm{a}}$ & ND \\
\hline 4 & ND & $2.47 \pm 0.61^{\mathrm{b}}$ & ND & ND & $0.74 \pm 0.64^{\mathrm{a}}$ & $0.74 \pm 0.64^{\mathrm{a}}$ & $0.70 \pm 0.21^{\mathrm{a}}$ & $0.54 \pm 0.50^{\mathrm{a}}$ \\
\hline \multicolumn{9}{|l|}{ Goats: } \\
\hline 0 & ND & ND & ND & ND & ND & ND & ND & ND \\
\hline 2 & ND & ND & ND & ND & ND & ND & ND & ND \\
\hline 4 & ND & ND & ND & $5.10 \pm 0.72^{\mathrm{b}}$ & ND & ND & ND & ND \\
\hline \multicolumn{9}{|l|}{ Camels: } \\
\hline 0 & ND & ND & ND & ND & ND & ND & ND & $0.34 \pm 0.26^{\mathrm{a}}$ \\
\hline 2 & ND & ND & $\mathrm{ND}$ & ND & ND & ND & ND & $1.12 \pm 0.40^{\mathrm{b}}$ \\
\hline 4 & $0.21 \pm 0.07^{\mathrm{b}}$ & $5.35 \pm 0.85^{\mathrm{c}}$ & $0.22 \pm 0.07^{\mathrm{a}}$ & ND & ND & ND & $4.82 \pm 1.88^{b}$ & $1.18 \pm 0.10^{\mathrm{b}}$ \\
\hline
\end{tabular}

${ }^{*}$ Values are means of triplicate determinations \pm Standard Deviations. ${ }^{1}$ In any column, means bearing similar superscripts are not significantly different $(\mathrm{P} \leq$ $0.05) .{ }^{2} \mathrm{ND}=$ Not Detected.

are namely: A. flavus, $A$. parasiticus, and $A$. nomius [27] [36]. The environmental conditions that influence toxin production most, appear to be temperature and water activity $\left(\mathrm{a}_{\mathrm{w}}\right)$; with the optimal temperature for toxin production being $24^{\circ} \mathrm{C}-28^{\circ} \mathrm{C}$ and that of $\mathrm{a}_{\mathrm{w}}$ is $0.93-0.98$ [27]. Control of mycotoxin production in foods is complex and difficult. There is insufficient information regarding toxicity, carcinogenicity, and teratogenicity to humans, stability of mycotoxins in foods, and extent of contamination. Such knowledge is required to establish guidelines and tolerance levels in food. Moreover, ingestion of large doses of aflatoxins have been reported to be acutely toxic, causing gross liver damage with intestinal and peritoneal hemorrhaging, resulting in death [22] [37]. Toxicity of aflatoxins have also been reported in decreasing order as $B_{1}>G_{1}>B_{2},>G_{2}$. Other foods in which aflatoxins may be produced include: peanuts, peanut butter, nuts, fresh beef, ham, bacon, milk, cheese (through contaminated feed to dairy cattle), beer, cocoa, raisins, soybean meal, corn, rice, wheat and cottonseed [26] [30] [32] [48] [52].

Finally, microbial food spoilage is a complex process. Fungal growth to high numbers is considered a prerequisite for the development of mycotoxins in 
many different types of food products, including meats. The sensory signs of fungal spoilage are many and varied; they may be visual (slime, swelling, discoloration), or be apparent by smell or taste (off-odours and off-flavours). These signs are typically a result of the accumulating by- and end-products formed during metabolic activity of the organisms, and none of these signs or spoilage indices were detected from any of the fried stored Sallah meats at the end of the four weeks storage period; indicating high level of hygiene in the preparation of the fried meats.

\section{Conclusion}

Among the desirable qualities that should be associated with foods is freedom from infectious organisms. Although it may not be possible to achieve a zero tolerance for all such organisms under good preparation practices, the production of foods with the lowest possible numbers should be a desirable goal. Harmful microbes may enter the manufacturing process and reach the end product in several ways: through raw materials, air in the preparation environment, ingredients employed, contact surfaces, or the handlers. There is high incidence of cancer among the inhabitants of Danbatta LGA in Kano; one of the major suspects of the cancer incidents in the area is the possible growth and toxin production in the fried Sallah meats consumed after an extended period of storage. This study has, however, confirmed the presence of fungal organisms in the fried Sallah meats, though not in significant numbers as to cause health risks to the consumers within the short storage time. The study concludes that the levels of aflatoxin $B_{1}, B_{2}, G_{1}$ and $G_{2}$ detected were far below the minimum lethal dosage and may not be associated with the high incidence of cancer in the area. The study however recommends that more hygienic processes be observed during Sallah meat preparations and handling, and that the meat should not be stored at ambient temperatures for more than four weeks.

\section{Acknowledgements}

The authors highly appreciate the Department of Food Science and Technology, Federal University Dutsin-ma, Katsina State; the Department of Food Science and Technology, University of Maiduguri, Borno State; Department of Biochemistry, Federal University Dutse, Jigawa State and the Department of Animal Science, University of Maiduguri, Borno State, for providing the resources and conducive research facilities used in this study.

\section{Conflicts of Interest}

The authors declare no conflicts of interest regarding the publication of this paper.

\section{References}

[1] Lambert, A.D., Smith, J.P. and Dodds, K.L. (1991) Shelf Life Extension and Micro- 
biological Safety of Fresh Meat-A Review. Food Microbiology, 8, 267-297. https://doi.org/10.1016/S0740-0020(05)80002-4

[2] Calkins, C.R. and Hodgen, J.M. (2007) A Fresh Look at Meat Flavour. Meat Science, 77, 63-80. https://doi.org/10.1016/j.meatsci.2007.04.016

[3] Heinz, G. and Hautzinger, P. (2007) Meat Processing Technology for Small-to-MediumScale Producers. Food and Agriculture Organization (FAO) of the United Nations. Regional Office for Asia and the Pacific, Bangkok.

[4] Biesalski, H.K. and Nohr, D. (2009) The Nutritional Quality of Meat. In: Kerry, J.P. and Ledward, D., Eds., Improving the Sensory and Nutritional Quality of Fresh Meat, Woodhead Publishing Ltd., Cambridge, 161-177. https://doi.org/10.1533/9781845695439.1.161

[5] Rao, V., Thulasi, G. and Ruban, S.J. (2009) Meat Quality Characteristics of Non Descript Buffalo as Affected by Age and Sex. World Applied Science Journal, 6, 1058-1065.

[6] Adeniyi, O.R., Ademosun, A.A. and Alabi, O.M. (2011) Proximate Composition and Economic Values of Four Common Sources of Animal Protein in South-Western Nigeria. Zootecnia Tropical, 29, 231-234.

[7] Olaoye, O.J. (2011) Meat: An Overview of Its Composition, Biochemical Changes and Associated Microbial Agents. International Food Research Journal, 18, 877-885.

[8] Adeyeye, S.A. (2016) Quality and Safety Assessment of Sun Dried Meat Product (Kundi) from Ibadan, Oyo State, Nigeria. Cogent Food and Agriculture, 2, Article ID: 1209074. https://doi.org/10.1080/23311932.2016.1209074

[9] Igwegbe, A.O., Idakwo, P.Y., Yusuf, H.L., Agbara, G.I., Maijalo, A.I. and Abubakar, F. (2019) Effects of Sodium Citrate and Garlic on Organoleptic Properties, Proximate Composition, Free Fatty Acid and Thiobarbituric Acid Levels of Treated Smoke-Died Meat Stored at Ambient Temperature. CPQ Medicine, 5, 2-14.

[10] Mayr, D., Margesin, R., Klingsbichel, E., Hartungen, E., Jenewein, D., Schinner, F., Märk, T.J.A. and Microbiology, E. (2003) Rapid Detection of Meat Spoilage by Measuring Volatile Organic Compounds by Using Proton Transfer Reaction Mass Spectrometry. Applied and Environmental Microbiology, 69, 4697-4705. https://doi.org/10.1128/AEM.69.8.4697-4705.2003

[11] Thippareddi, H. and Sanchez, M. (2006) Thermal Processing of Meat Products. In: Sun, D.W., Ed., Thermal Food Processing. New Technologies and Quality Issues, Taylor and Group CRC Press, New York, 156-192.

[12] Norrung, B., Anderson, J.K. and Buncie, S. (2009) Main Concerns of Pathogenic Microorganism. In: Toldra, F., Ed., Meat Safety and Processed Meats, Springer Publishing, New York, 3-29. https://doi.org/10.1007/978-0-387-89026-5_1

[13] Zukal, E. and Incze, K. (2010) Drying. In: Fidel, T., Ed., Handbook of Food Processing, Wiley-Blackwell, Hoboken, Chapter 11, 219-229. https://doi.org/10.1002/9780813820897.ch11

[14] Samuel, O., Obika, I., Odibo, F. and Orji, M. (2015) An Assessment of the Bacteriological Quality of Tsire-Suya (Grilled Beef) Sold in Awka, Nigeria. American Journal of Life Sciences Research, 3, 287-292. https://doi.org/10.21859/ajlsr-040301

[15] Olaoye, O.A., Onilude, A.A., Idowu, O.A. and Technology, B. (2010) Microbiological Profilof Goat Meat Inoculated with Lactic Acid Bacteria Cultures and Stored at 3 ${ }^{\circ} \mathrm{C}$ for 7 Days. Food and Bioprocess Technology, 4, 312-319. https://doi.org/10.1007/s11947-010-0343-3

[16] Uzeh, R.E., Akinyemi, M.O. and Nduaguba, C.C. (2012) Microbiological and Physico Chemical Characteristics of Stored Tsire-Suya, a Roasted Meat Product. Inter- 
national Journal of Biological and Chemical Sciences, 6, 1804-1809. https://doi.org/10.4314/ijbcs.v6i4.35

[17] Manyi, M.M., Idu, O.F. and Ogbonna, I.O. (2014) Microbiological and Parasitic Quality of Suya (Rosted Beef) Sold in Makurdi, Benue State, Nigeria. African Journal of Microbiology Research, 8, 3235-3242. https://doi.org/10.5897/AJMR2014.6897

[18] Lawrence, O.A., Faith, O.S., Ruth, E. and Nathaniel, N.N. (2016) Bacterial Status and Anti-Bacterial Susceptibility Profies of Selected Pathogens Associated with Suya Samples Purchased in Bori, Metropolis, Rivers State, Nigeria. International Research Journal of Public Environment and Health, 3, 14-19.

[19] Yusuf, H.L., Igwegbe, A.O., Idakwo, P.Y. and Ismail, B.B. (2019) Process Standardization Using Sensory Evaluation of Kamsa: A Smoked-Dried Meat. Proceedings of the 43rd Conference of the Nigerian Institute of Food Science and Technology, Awka, 14-18 October 2019, 3-4.

[20] Mead, G.C. (2004) Microbiological Quality of Poultry Meat: A Review. Brazilian Journal of Poultry Science, 6, 135-142. https://doi.org/10.1590/S1516-635X2004000300001

[21] Igene, J.O., Farouk, M.M. and Akanbi, C. (2009) Preliminary Studies on the Quality and Drying Characteristics of "Suya". Nigeria Food Journal, 7, 29-38.

[22] Shaltout, F.A., Amin, R.A., Nassif, M.Z. and Abd-elwahab, S.A. (2014) Detection of Aflatoxins in Some Meat Products. Benha Veterinary Medical Journal, 27, 368-374.

[23] FAO/WHO (2004) Expert Committee on Food Additives. Evaluation of Certain Veterinary Drug Residues in Food: Sixty-Second Report of the Joint FAO/WHO Expert Committee on Food Additives. Food and Agriculture Organization, Rome.

[24] Rodricks, J.V. and Stoloff, L. (1977) Aflatoxin Residues from Contaminated Feed in Edible Tissues of Food Producing Animals. In: Rodricks, J.V., Heseltine, C.W. and Mehlman, M.A., Eds., Mycotoxins in Human and Animal Health, Pathotox Publishers, Inc., Park Forest South, IL, 67-79.

[25] Mor-Mur, M. and Yuste, J. (2010) Emerging Bacterial Pathogens in Meat and Poultry: An Overview. Food and Bioprocess Technology, 3, 24. https://doi.org/10.1007/s11947-009-0189-8

[26] Ray, B. (2004) Spoilage of Specific Food Groups. In: Fundamental Food Microbiology, 3rd Edition, CRC Press, New York, 270-287.

[27] Lawley, R., Curtis, L. and Davis, J. (2008) Biological Toxins. In: The Food Safety Hazard Guidebook, The Royal Society of Chemistry (RSC) Publishing, Cambridge, 179-184.

[28] Ashiq, S.J. and Safety, F. (2015) Natural Occurrence of Mycotoxins in Food and Feed: Pakistan Perspective. Comprehensive Reviews in Food Science and Food Safety, 14, 159-175. https://doi.org/10.1111/crf3.2015.14.issue-2

[29] Jeswal, P. and Kumar, D.J. (2015) Mycobiota and Natural Incidence of Aflatoxins, Ochratoxin A, and Citrinin in Indian Spices Confirmed by LC-MS/MS. International Journal of Microbiology, 2015, Article ID: 242486. https://doi.org/10.1155/2015/242486

[30] Jonathan, S. and Esho, E.J. (2010) Fungi and Aflatoxin Detection in Two Stored Oystermushrooms (Pleurotus ostreatus and Pleurotus pulmonarius) from Nigeria. Electronic Journal of Environmental, Agricultural and Food Chemistry, 9, 1722-1730.

[31] Bayman, P. and Baker, J.L. (2006) Ochratoxins: A Global Perspective. Mycopathologia, 162, 215-223. https://doi.org/10.1007/s11046-006-0055-4 
[32] Asan, A., Kirgiz, T., Sen, B., Camur-Elipek, B., Guner, U. and Guher, H.J. (2003) Isolation, Identification and Seasonal Distribution of Airborne and Waterborne Fungi in Terkos Lake (Istanbul-Turkey). Journal of Basic Microbiology, 43, 83-95. https://doi.org/10.1002/jobm.200390017

[33] El-Bouhy, Z.M., Ali, A.A. and Helmy, M.S (1993) Pre-Liminary Studies on Aflatoxicosis of Contaminated Food. Zagazig Veterinary Journal, 21, 607-624.

[34] Reiman, H.P. and Cliver, D.O. (2006) Foodborne Infections and Intoxications. 3rd Edition, Elsevier Inc., London.

[35] Richard, J.L. (2007) Some Major Mycotoxins and Their Mycotoxicoses-An Overview. International Journal of Food Microbiology, 119, 3-10. https://doi.org/10.1016/j.ijfoodmicro.2007.07.019

[36] Jay, J.M., Loessner, M.J. and Golden, D.A. (2005) Modern Food Microbiology. 7th Edition, Springer Science + Business Media Inc., New York.

[37] Shephard, G.S. (2008) Determination of Mycotoxins in Human Foods. Chemical Society Reviews, 37, 2468-2477. https://doi.org/10.1039/b713084h

[38] Banwart, G. (2012) Basic Food Microbiology, Springer Science and Business Media, Berlin.

[39] Abdullahi, F.S., Igwegbe, A.O., Bello, A.B., Abashe, S., Adam, I.K. and Badau, M.H. (2019) Assessment of Microbial Quality of Balangu-Dipping Water from Six Outlets in Wudil Town in Kano State, Nigeria. International Journal of Food Science and Technology, 9, 1-12.

[40] Quinn, P.J., Carter, M.E., Markey, B. and Carter, G.R. (2002) Clinical Veterinary Microbiology. Mosby International Ltd., London, 42-49.

[41] Vipul, V., Singh, R., Tiwari, R.K., Srivastava, N. and Verma, A. (2012) Antibacterial Activity of Extracts of Citrus, Allium \& Punica against Foodborne Spoilage. Asian Journal of Plant Science and Research, 2, 503-509.

[42] Igwegbe, A.O., Kassum, A.L., Maina, F.J., Bristone, C., Abubakar, F., Imam, H.O., Lawan, H.K. and Adam, F.M. (2019b) Effects of Sodium Citrate and Garlic on pH and Microbial Stability of Smoke-Dried Meat Stored at Ambient Temperatures. In: Opara, J.A., Ed., Health, Environment and Sustainable Development. A Book of Readings in Honour of Professor Ibrahim Njodi, University of Maiduguri Press, Maiduguri, Chapter 23, 226-240. http://www.unimaid.edu.ng

[43] Cheesbrough, M. (2006) District Laboratory Practice in Tropical Countries. 2nd Edition, Cambridge University Press, Cambridge, 47-54. https://doi.org/10.1017/CBO9780511543470

[44] Gong, X., Wang, H., Zhang, Y., Sun, J., Dong, J., Lin, L., Yu, J., Feng, Z. and Li, K.J. (2012) Determination of 15 Mycotoxins in Foods and Feeds Using High Performance Liquid Chromatography-Tandem Mass Spectrometry with Gel Permeation Chromatography Combined QuEChERS Purification. Journal of Chromatography and Separation Technique, 3, 125. https://doi.org/10.4172/2157-7064.1000125

[45] Dean, A., Voss, D. and Draguljic, D. (2017) Design and Analysis of Experiments. 2nd Edition, Springer International Publishing, New York. https://doi.org/10.1007/978-3-319-52250-0

[46] Holzapfel, W.H. (1998) The Gram-Positive Bacteria Associated with Meat and Meat Products. In: Davies, A. and Board, R., Eds., The Microbiology of Meat and Poultry, Blackie Academic \& Professional, London, 35-84.

[47] Stanbridge, L.H. and Davies, A.R. (1998) The Microbiology of Chilled-Stored Meat. In: Board, R.G. and Devies, A.R., Eds., The Microbiology of Meat and Poultry, Blackie Academic and Professional, London, 174-219. 
[48] Wafia, H.A. and Hassan, A.A. (2002) Sanitary Status of Some Ready to Eat Meat Meals in Cairo and Giza Governorate. Journal of the Egyptian Veterinary Medical Association, 60, 95-104.

[49] Shafiur Rahman, M. and Perera, C.O. (2007) Drying and Food Preservation. In: Shafiur Rahman, M., Ed., Handbook of Food Preservation, 2nd Edition, CRC Press, New York, 403-432. https://doi.org/10.1201/9781420017373

[50] Roos, Y.H., Finley, J.W. and deMan, J.M. (2018) Water. In: de Man, J.M., Hurt, W.J., Finley, J.W. and Lee, C.Y., Eds., Principles of Food Chemistry, 4th Edition, Springer International Publishing, Cham, 1-38. https://doi.org/10.1007/978-3-319-63607-8_1

[51] Marriotti, N.G. and Gravani, R.B. (2006) Relationship of Microorganisms to Sanition. In: Principles of Food Sanitation, 5th Edition, Springer Science + Business Media Inc., New York, 25-69.

[52] Sofos, J.N. (2008) Challenges to Meat Safety in the 21st Century. Meat Science, 78, 3-13. https://doi.org/10.1016/j.meatsci.2007.07.027 